\title{
Conference report: the 5th Asia Pacific Protein Association Conference joint meeting with the 12th International Symposium of the Protein Society of Thailand
}

\author{
James R. Ketudat Cairns ${ }^{1,2}$ - Voraratt Champattanachai ${ }^{1}$ - Chantragan Srisomsap ${ }^{1}$. \\ N. Monique Paricharttanakul ${ }^{1}$ - Chris Verathamjamras ${ }^{1} \cdot$ Kriengsak Lirdprapamongkol $^{1}$ • \\ Jisnuson Svasti ${ }^{1}$
}

Received: 10 August 2017 / Accepted: 11 August 2017 / Published online: 7 September 2017

(C) International Union for Pure and Applied Biophysics (IUPAB) and Springer-Verlag GmbH Germany 2017

The 5th Asia Pacific Protein Association Conference and 12th International Symposium of the Protein Society of Thailand (APPA/PST2017) was held at The Tide Resort, Bangsaen, Chonburi, Thailand, from the 11th to the 14th of July, 2017 (Fig. 1). It was hosted by the Protein Society of Thailand, Chulabhorn Research Institute, and Burapha University, in honor of the 60th birthday of Professor Dr. H.R.H. Chulabhorn Mahidol, the President of the Chulabhorn Research Institute, and a prolific contributor to chemical and biomedical research, as well as related social issues.

The Asia Pacific Protein Association (APPA; http:// www.pssj.jp/APPA/about/overview/) grew from the Pacific Rim International Conference on Protein Structure (PRICPS), which was first held in Yokohama, Japan, in 2004. After that outstanding meeting, the organizers endeavored to continue in its tradition to organize the 2nd PRICPS in Cairns, Australia, in 2008 in conjunction with the Asia Oceania Human Proteome Organization (AOHUPO) Congress. At that meeting, the Asia Pacific Protein Association was formed, with the main purpose of organizing protein structure and function in the Asia Pacific region, in order to promote the development of

James R. Ketudat Cairns

cairns@sut.ac.th

1 Laboratory of Biochemistry, Chulabhorn Research Institute, Bangkok 10210, Thailand

2 School of Chemistry, Institute of Science and Center for Biomolecular Structure, Function and Application, Suranaree University of Technology, Nakhon Ratchasima 30000, Thailand protein science and collaboration. Subsequently, the 3rd APPA Conference was held in Shanghai, China, in 2011, and the 4th APPA Conference in Jeju, Korea, in 2014, followed by this, the 5 th in this series.

The Protein Society of Thailand (PST; www. proteinsocthai.net) originated from similar goals to build a network of scientists working on proteins and to provide a forum for them to exchange their research and ideas. This network developed into the society known at the PST, which has held the conference series now called the International Symposium of the PST since 2006, at which international and local invited speakers, including senior scientists and notable young scientists, share their work in English to promote international interactions.

The APPA/PST2017 meeting included 7 plenary lectures, led by Thomas Steitz, who regaled the assembled group of 400 participants with his description of the ribosome structure and the use of bacterial ribosome structures in designing improved antibiotics (Fig. 1). In the second plenary, M.R. Jisnuson Svasti described the development of protein science in Thailand using illustrations from his own career. This was followed by the EMBO Keynote Lecture by Madan Babu, in which he described the importance of intrinsically disordered proteins and protein regions at a proteome- and genome-wide level. In his plenary, So Iwata described the use of the free electron laser to gain temporal insight into light-initiated reactions in bacterial rhodopsin and the photosystem II oxygen-evolving complex, while Ruiming Xu considered the structural basis of epigenetics, particularly histone acetylation and deacetylation. In the penultimate plenary, Akhilesh Pandey explored the identification and validation of protein-protein interactions in cells as the current frontier in 


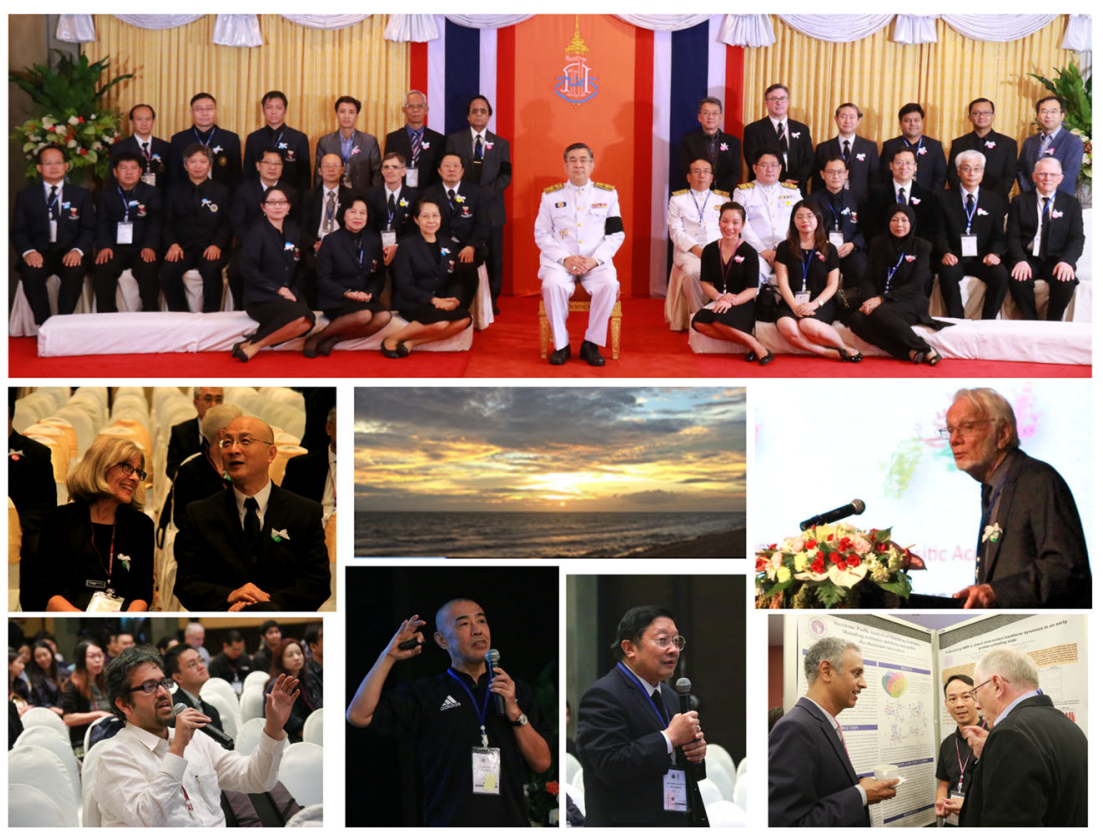

Fig. 1 Scenes from the 5th Asia Pacific Protein Association Conference/ 12th International Symposium of the Protein Society of Thailand. Clockwise from top: The PST and APPA Councils are photographed with the representative of Prof. Dr. HRH Chulabhorn, Surapit Kirtiputra, during the Opening Ceremony; Thomas Steitz entertains the audience with the rhythms of the ribosome; Akhilesh Pandey discusses a poster with
Richard Simpson; Jisnuson Svasti comments on another speaker's talk; So Iwata answers a question after his plenary; Madan Babu poses a question to another speaker; Carol B. Post and Ruiming Xu share a light moment during preparation for the Opening Ceremony; and center: sunset on the beach in front of the hotel at the end of the conference proteomics. Carol B. Post presented the final plenary, "The Protein Society Keynote Lecture," in which she described an unusual mechanism for regulation of protein-protein interactions by phosphorylation in Syk tyrosine kinase.

Interspersed among the plenary lectures were 43 invited and 25 selected oral lectures, divided into 17 parallel sessions. These sessions focused on diverse areas of protein research, from advances in proteomics, systems biology and bioinformatics to structural investigations of protein-nucleic acid interactions and molecular processes, enzyme catalysis, dynamics of protein-protein interactions and signaling, as well as protein engineering to achieve new protein activities. Outstanding scientists from around the Asia Pacific region, together with Prof. Joan Steitz from the USA, were featured as invited speakers (Table 1). An 18th session honoring the 70th birthday of Prof. M.R. Jisnuson Svasti featured outstanding Thai protein scientists who have worked with Prof. Svasti during the development of their careers. Furthermore, a Systems Biology and Computational Biology Workshop, in which senior and local scientists shared their experiences and discussed their research and related issues, was included in the afternoon parallel sessions of 12th July, while the Synchrotron Light Research Institute (SLRI) sponsored a workshop on
Synchrotron Protein Research in the afternoon of 13th July to introduce researchers to the facilities available at the SLRI in Thailand, as well as in the National Synchrotron Radiation Research Center (NSRRC), Taiwan, China, and the SPring-8 facilities in Japan.

In addition to the lectures, 5 poster sessions allowed participants ample time to discuss the excellent work of young and a few senior scientists presenting in these sessions. Luncheon lectures from Bio-Rad, GE and Merck introduced participants to ways of collaborating with the companies, along with some of the latest technologies available from these companies, while other companies presented their products in the exhibition. Several young scientists also took advantage of the Young Scientist Program held just ahead of the conference (9th to 11th July) to learn from senior protein researchers and present their own research in short talks.

In short, the APPA/PST2017 conference provided an exciting forum for protein science, with some of the world's top protein scientists sharing their research results, with particular emphasis on research from the Asia Pacific region. The high quality of the research presented bodes well for the future meetings of the APPA, including the 6th APPA Conference to be held 
Table 1 Invited lectures

\begin{tabular}{|c|c|c|}
\hline Invited Speaker & Session & \\
\hline Norie Araki & PS12 & Kumamoto University, Japan \\
\hline Salvador Eugenio Caoili & PS9 & $\begin{array}{l}\text { University of the Philippines, } \\
\text { Manila, } \\
\text { The Philippines }\end{array}$ \\
\hline Pimchai Chaiyen & JS $70 \mathrm{yr}$ & $\begin{array}{l}\text { VISTEC and Mahidol University, } \\
\text { Thailand }\end{array}$ \\
\hline Zengyi Chang & PS6 & Peking University, China \\
\hline Yun-Ru (Ruby) Chen & PS3 & $\begin{array}{l}\text { Genome Research Center, } \\
\text { Academia Sinica, Taiwan }\end{array}$ \\
\hline Maxey C.M. Chung & PS9 & $\begin{array}{l}\text { National University of Singapore, } \\
\text { Singapore }\end{array}$ \\
\hline Yuji Goto & PS6 & Osaka University Japan \\
\hline Damien Hall & PS1 & $\begin{array}{l}\text { Australian National University, } \\
\text { Osaka University, Japan }\end{array}$ \\
\hline $\begin{array}{l}\text { Chwan-Deng } \\
\text { (David) Hsiao }\end{array}$ & PS15 & Academia Sinica, Taiwan \\
\hline Mitsunori Ikeguchi & PS1 & Yokohama University, Japan \\
\hline Syed Rashel Kabir & PS10 & University of Rajshahi, Bangladesh \\
\hline Yangmee Kim & PS8 & Konkuk University, Korea \\
\hline Kurt Krause & PS8 & University of Otago, New Zealand \\
\hline Ubolsree Leartsakulpanich & PS7 & $\begin{array}{l}\text { National Center for Genetic } \\
\text { Engineering and Biotechnology, } \\
\text { Thailand }\end{array}$ \\
\hline Erinna F. Lee & PS7 & La Trobe University, Australia \\
\hline Jooyoung Lee & PS1: & $\begin{array}{l}\text { Korea Institute of Advanced Study, } \\
\text { Korea }\end{array}$ \\
\hline Weontae Lee & PS15: & Yonsei University, Korea \\
\hline
\end{tabular}

\begin{tabular}{|c|c|c|}
\hline Zhenfeng Liu & PS10 & Institute of Biophysics (CAS), China \\
\hline Ping-Chiang Lyu & PS7 & National Tsing-Hua University, Taiwan \\
\hline Jacqueline Matthews & PS13 & University of Sydney, Australia \\
\hline Osamu Nureki & PS13 & University of Tokyo, Japan \\
\hline
\end{tabular}

Ray Norton

Truong Quoc Phong

Piamsook Pongsawasdi

Terence Poon

Mohan Rao
PS3

PS3 Monash University, Australia

PS4

Hanoi University of Science and Technology, Vietnam

JS 70 years Chulalongkorn University, Thailand

PS11 University of Macau, Macau, China

Centre for Cellular \& Molecular Biology, India
"Systems biology of cancer stem cells by integrated proteomics and glycomics"

"Antibodies, synthetic peptides and related constructs for planetary health under the precautionary regime of the contemporary Anthropocene"

"Flavin-dependent monooxygenases for sustainable technology"

"The biogenesis and quality control of beta-barrel outer membrane proteins in Gram-negative bacteria"

"Understanding TDP-43 oligomers and dipeptide repeats in neurodegenerative diseases"

"Mining the cancer secretome as a source for biomarkers"

"Supersaturation-limited phase transitions of denatured proteins producing amyloid fibrils"

"Physical biochemistry studies of amyloid"

"Structure and function of the polymyxin-resistance-associated response regulator PmrA"

"Molecular dynamics simulations of molecular rotary motors"

"Therapeutic evaluation of plant lectins as promising anticancer agents"

"Structures and dynamics of acyl carrier proteins from multi-drug resistant bacteria"

"Glutamate racemase from Mycobacterium tuberculosis is a new target for antituberculosis drug design"

"Serine hydroxymethyltransferase for antimalarial drug"

"Disarming the critical drivers of cancer"

"Protein structure prediction/determination by global optimization"

"Oligomerization and adapter molecule interaction of proteoglycans reveals a unique molecular function related to cancer signaling"

"Supramolecular basis for the light-harvesting processes in plants"

"Structural insights into the catalytic mechanism of dopamine N-acetyltransferase"

"Assembly of an activating transcription factor complex"

"Molecular mechanism of CRISPR and structure-based development of genome editing tool towards medical application"

"Structural and dynamic aspects of antibody recognition of intrinsically disordered antigens"

"Production of rotavirus recombinant VP6 protein and its specific antibody for development of the lateral flow immunoassay test strip"

"Glycosyltransferases for the synthesis of oligosaccharides and glycosides"

"Application of proteomics approaches to discovery of biomarkers in cancer diagnosis - An impossible mission?"

"Clusterin: full-length protein and one of its chains show opposing effects on cellular lipid accumulation" 
Table 1 (continued)

\begin{tabular}{|c|c|c|c|}
\hline Invited Speaker & Session & & \\
\hline Gavin Reid & PS2 & University of Melbourne, Australia & $\begin{array}{l}\text { "An integrated "omics approach toward understanding the } \\
\text { role of aberrant lipid metabolism in colon cancer" }\end{array}$ \\
\hline Polkit Sangwanich & PS2 & Chulalongkorn University, Thailand & $\begin{array}{l}\text { "Plant proteomics and their potential approaches in various } \\
\text { applications" }\end{array}$ \\
\hline Rajan Sankaranarayanan & PS14 & $\begin{array}{l}\text { Centre for Cellular \& Molecular } \\
\text { Biology, India }\end{array}$ & $\begin{array}{l}\text { "Chiral proofreading: mechanism and functional } \\
\text { implications" }\end{array}$ \\
\hline Ichio Shimada & PS15 & University of Tokyo, Japan & $\begin{array}{l}\text { "Developments and applications of novel NMR methods } \\
\text { to characterize functional dynamics of high molecular } \\
\text { weight proteins" }\end{array}$ \\
\hline Nikhat Ahmed Siddiqui & PS9: & Barrett Hodgson University, Pakistan & $\begin{array}{l}\text { "Understanding the molecular basis and complexity of } \\
\text { Schizophrenia through neuroproteomics and } \\
\text { interactomics" }\end{array}$ \\
\hline Richard Simpson & PS2: & La Trobe University, Australia & $\begin{array}{l}\text { "Proteogenomic profiling of secreted colon cancer } \\
\text { extracellular vesicle subtypes: functional insights" }\end{array}$ \\
\hline Joan Steitz & PS13 & Yale University, USA & "Nuclear noncoding RNAs: more surprises" \\
\hline Chantragan Srisomsap & JS 70 years & $\begin{array}{l}\text { Chulabhorn Research Institute, } \\
\text { Thailand }\end{array}$ & "Cancer proteomics and marker discovery" \\
\hline Bambang Sugiharto & PS10 & Jember University, Indonesia & $\begin{array}{l}\text { "The function and regulation of sucrose-phosphate synthase } \\
\text { from sugarcane" }\end{array}$ \\
\hline Wipa Suginta & PS8 & $\begin{array}{l}\text { Suranaree University of } \\
\text { Technology, Thailand }\end{array}$ & $\begin{array}{l}\text { "Structural and biophysical insights into chitin acquisition by } \\
\text { marine Vibrios" }\end{array}$ \\
\hline Ratchanok Tinikul & PS14 & Mahidol University, Thailand & $\begin{array}{l}\text { pH effect study for exploring enzyme mechanisms-case } \\
\text { studies from bacterial luciferase and succinic semialdehyde } \\
\text { dehydrogenase }\end{array}$ \\
\hline Ming Daw Tsai & PS14 & Academia Sinica, Taipei, Taiwan & $\begin{array}{l}\text { "Structural mechanism for the fidelity modulation of DNA } \\
\text { polymerase } \lambda "\end{array}$ \\
\hline Kouhei Tsumoto & PS4: & University of Tokyo, Japan & $\begin{array}{l}\text { "Recent progress on the analytical solutions for } \\
\text { bio-pharmaceutics" }\end{array}$ \\
\hline Xinquan Wang & PS5: & Tsinghua University, China & $\begin{array}{l}\text { "MERS and SARS coronavirus cell entry: from structure to } \\
\text { neutralizing antibody." }\end{array}$ \\
\hline Sopit Wongkham & PS12 & Khon Kaen University, Thailand & $\begin{array}{l}\text { "Glycomic analysis reveals the significance of high mannose } \\
\text { N-glycan in progression of cholangiocarcinoma." }\end{array}$ \\
\hline Yeon Gyu Yu & PS11 & Kookmin University, Korea & $\begin{array}{l}\text { "A novel method for the preparation and stabilization of } \\
\text { membrane proteins and its application for the biochemical } \\
\text { analysis of GPCRs." }\end{array}$ \\
\hline $\begin{array}{l}\text { Raja Noor Zaliha } \\
\text { Raja Abd. Rahman }\end{array}$ & PS4 & University Putra Malaysia, Malaysia & $\begin{array}{l}\text { "A thermotolerant lipase with broad } \mathrm{pH} \text { isolated from Antarctic } \\
\text { Pseudomonas sp. AMS3" }\end{array}$ \\
\hline
\end{tabular}

in Sapporo, Japan, in July, 2020, in collaboration with the Protein Science Society of Japan and the Protein Society.

\section{Compliance with ethical standards}

Conflicts of interest James R. Ketudat Cairns declares that he has no conflicts of interest. Voraratt Champattanachai declares that he has no conflicts of interest. Chantragan Srisomsap declares that she has no conflicts of interest. N. Monique Paricharttanakul declares that she has no conflicts of interest. Chris Verathamjamras declares that he has no conflicts of interest. Kriengsak Lirdprapamongkol declares that he has no conflicts of interest. Jisnuson Svasti declares that he has no conflicts of interest.

Ethical approval This article does not contain any studies with human participants or animals performed by any of the authors. 